\title{
Promoting the effective use of water in the irrigation of permanent crops in the Western Cape Province of South Africa
}

\author{
A. S. Roux \\ Department of Agriculture, Western Cape, South Africa
}

\begin{abstract}
South Africa is an arid country with an average annual rainfall of little more than half the world average of $900 \mathrm{~mm}$ per annum. In terms of international norms, the per capita availability of water will lead to a "water-stressed" country classification soon. The competition for water increase and the irrigation sector, that is responsible for more than $50 \%$ of the water usage, will have to get involved to find balanced solutions to the looming water shortage crisis.

This provided the motivation in 1998 for the Department of Agriculture in the Western Cape Province of South Africa to start with the Agricultural Water Conservation Project. The aim of the project is to monitor the actual on-farm irrigation water use and to compare the water use with the farming practices applied by the individual farmers and to compare it with the theoretical calculated water requirements.

The optimum farming practices that lead to optimum use of irrigation water will be determined from the data collected and can then be used to assist other irrigation farmers to increase their water use efficiency (WUE - $\mathrm{kg}$ of fruit produced per $\mathrm{m}^{3}$ water used) and to determine what research is required in this field. A Best Management Practices document will be compiled and distributed at the end of the project to assist all irrigation farmers to increase their WUE.

Keywords: water use efficiency, best management practices, irrigation, plant water requirements, water conservation, agriculture.
\end{abstract}

\section{Background}

Water is a scare resource across South Africa and also in the Western Cape. Water usage by the Western Cape agricultural sector amounts to more than $43 \%$ 
of the total water usage and there remain few catchment areas where additional water can be allocated to the agricultural sector. Extension of existing irrigation will have to be derived from savings in current water usage levels.

The national Water Act, 1998 (Act 36 of 1998), demands the economical and sustainable usage and efficient management of water usage. Proof must also be given of the effectivity of existing water usage before licenses for the use of water will be issued or renewed in future.

The graph below indicates the usage for the various sectors in the Western Cape.

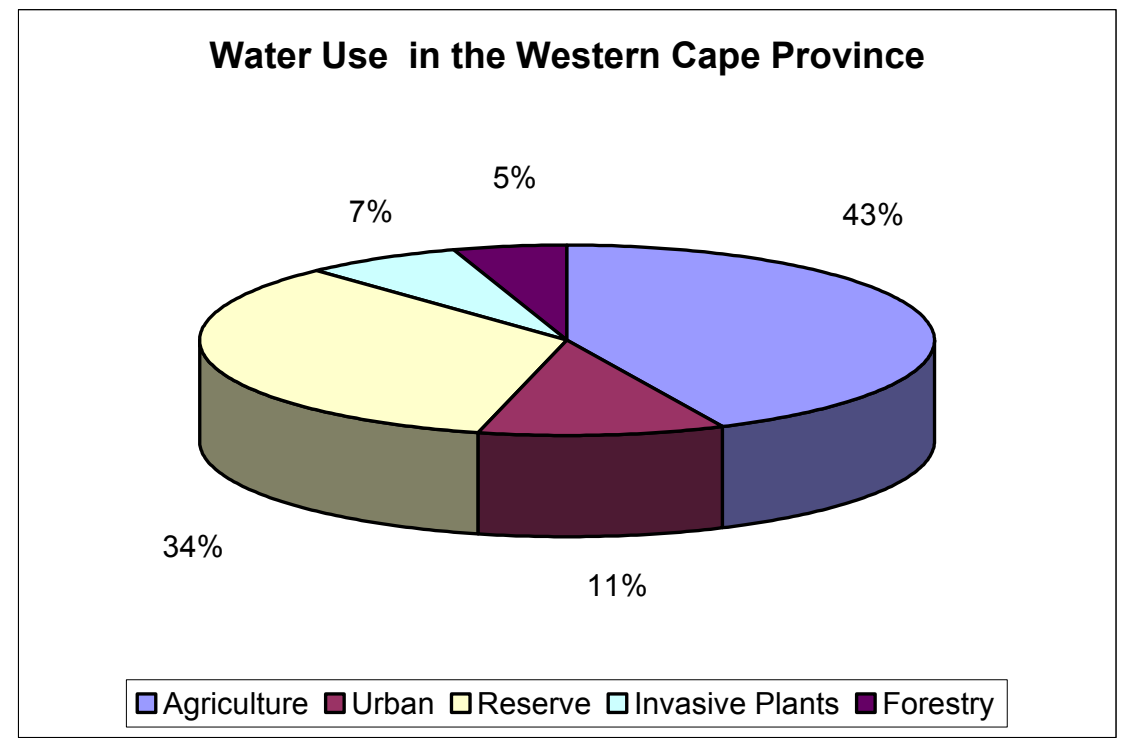

Figure 1: Water use by the different sectors in the Western Cape Province.

\section{Possible effects of water conservation in the agricultural sector}

Agriculture uses approximately 160 million $\mathrm{m}^{3}$ water per year from the Berg/Riviersonderend system. The annual increase in the demand for water from this system amounts to approximately 20 million $\mathrm{m}^{3}$ of which 5 million $\mathrm{m}^{3}$ is needed for agricultural usage.

The result of more effective usage of water by the agricultural sector is illustrated by the following statement: a saving of $10 \%$ in agricultural water usage represents a volume of 16 million $\mathrm{m}^{3}$ per year, which is enough to provide for the increase of the agricultural demand for water for the next three years, by which time the demand could be further decreased due to water conservation measures. 
The rivalry for water will continually increase and the irrigation sector, which is responsible for $50 \%$ of the water usage in the country, will have to become more involved in the quest for balanced solutions within the agricultural sector and between agriculture and other water users. Water saving can have a huge impact on the construction of future water supply schemes at enormous costs and can have a direct and positive influence on the economy of the Western Cape.

\section{Reasons for the ineffective use of irrigation water}

Ineffective water usage at farm level can be attributed to the following:

- Poor designs of irrigation systems

- Inadequate maintenance of irrigation systems

- Ignorance regarding irrigation scheduling

- Sub standard application of irrigation scheduling

- Complexity of farming and irrigation management

- Lack of tried, practical and accessible information

- Lack of training of water managers on the farms

- Relative low cost of water in relation to other input costs

In order to improve the situation the Department of Agriculture: Western Cape initiated an investigation into the water use efficiency (WUE) of four main irrigation crops in the winter rainfall region. For the purpose of this project WUE can be defined as the quantity of fruit $(\mathrm{kg})$ produced per unit irrigation water $\left(\mathrm{m}^{3}\right)$ applied.

\section{Objectives of the Agricultural Water Conservation Project}

The objectives of the project can be summarized as follows:

- Promote the efficient use of water on farm level by documenting management practices that result in water savings. Hereby, optimal farming practices (including irrigation) that promote the effective use of water at farm level can be determined.

- Determine why certain producers achieve higher levels of effective water usage than others.

- Assist participants in the study that have poor levels of water savings to increase their efficiency.

- Compile a list of Best Management Practices for distribution amongst producers.

- Thus the water use efficiency of the broader irrigation sector in the Western Cape can be increased.

- Information derived from the project will be used to identify extension and research actions to increase the WUE of all crops in the Province. 


\section{Methodology}

In order to determine the optimal use of water, the water use and yield (quantity and quality) of various producers were compared, considering the farming practices applied. Four crop types were chosen to represent the main irrigation practices in the Western Cape - wine grapes, table grapes, pears and plums. The following areas were chosen for monitoring the various crop types:

$\begin{array}{ll}\text { Worcester (Worcester East) } & \text { Wine grapes } \\ \text { De Doorns (Hex River Valley) } & \text { Table grapes } \\ \text { Ceres (Koekedouw) } & \text { Pears } \\ \text { Stellenbosch (Devon Valley) } & \text { Plums }\end{array}$

In order to ensure involvement and cooperation from the agricultural sector, the following procedure was followed:

- Meetings were held in the various regions to inform producers about the objectives of the project and to convince them to take part in the project

- Experts such as soil experts, economists and a statistician were involved.

- A soil survey was done on the farms where producers agreed to be part of the project. After consultation with the experts of every region a decision was made about the irrigation blocks that conform to the requirements. The aim was to choose blocks of the same cultivars, of approximately the same age, planted in the same type of soil and in a similar micro climate.

- A project committee was composed for every region, including soil, irrigation and crop specialists, as well as a representative of the irrigators. The four project committees reported to the Steering Committee, which evaluated results from time to time and advised the project committees. The project committees met three times per year to evaluate progress.

- A rain meter and water meter were installed at each block. Producers contributed half of the cost of these meters.

\section{Monitoring of farming practices and water consumption}

\subsection{9/2000 irrigation season}

Various soil and system parameters for all irrigation blocks were obtained in order to gain base line information. This included the following:

- Completion of a questionnaire to gain information regarding the crop, soil preparation practices, irrigation systems and the source of water. Farming practices were also noted.

- Soil samples were taken to determine the soil moisture release curve, water retention ability as well as the texture.

- In-field evaluation of the identified irrigation blocks 
- Two weekly gravimetrical soil water determination

- Weekly reading of water and rain meters

- Two weekly noting of weed growth

- Monthly determining of the conductivity of the irrigation water. If the reading was $80 \mathrm{mS} / \mathrm{m}$ an analytical laboratory did a complete water analysis.

- Five weekly determining of the vigour of the shoots.

- Problem soils were analysed for salinity just prior to harvesting season and where possible, the quality of the drainage water was determined monthly.

- Information regarding the climate for the harvesting season was obtained from the closest weather station.

- The yield per block is obtained from the wine cellars or pack stores.

- After the season the producers were informed about the shortcomings of their irrigation systems and corrections were made where practical and economically viable.

- Advice provided regarding effective pressure control, as well as the supply of guidelines for improved maintenance of the irrigation systems.

\subsection{Irrigation seasons: 2000/01 up to 2003/04}

- The measurement of water usage, rainfall, weed growth and the vigour of the crops were continued in every season.

- In certain areas more irrigation blocks were included in the study to fill in certain gaps in the information gathered.

- Frequent soil moisture measurements were done by scheduling experts and recommendations were made to the producers. The Department and producers share the costs involved with this action.

- Continuous training was given to all individuals involved with water management on the participating farms

\section{Results of the project}

Space limits the detail of the results and the factors that played a role in each year that can be provided in this paper. Only a summary of each area is provided.

\subsection{Wine grapes: Colombar cultivar: Worcester East}

From figure 2 below it is evident that the cumulative water usage exceeded the theoretical gross irrigation requirement (blue line without marks) in only two irrigation blocks out of the total of seven. This indicates that irrigation water is already being used efficiently and that irrigators in this area, which is fairly water poor, have learned to use the available water efficiently.

Indication is that more water is given during the early part of the season compared to the theoretical calculated demand. It also indicates that four of the producers do not compensate for the higher water demand of the crop during the 
latter phenological stages of the season. In some cases this can be attributed to a shortage of water during the last part of the irrigation season.

The actual production measured per hectare of the participating irrigation blocks are indicated in Figure 3 below. In order to compensate for a higher quality grape produced, the actual sugar tonnage produced were recorded instead of just normal tonnage production.

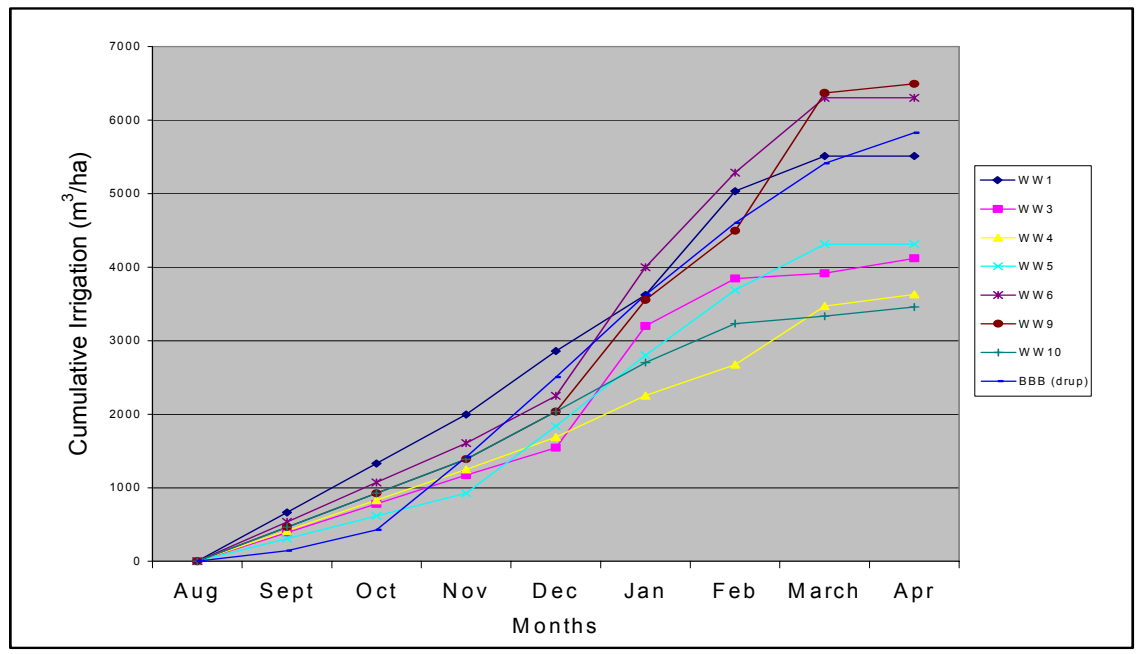

Figure 2: $\quad$ Cumulative water use Colombar wine grapes 2000/2001.

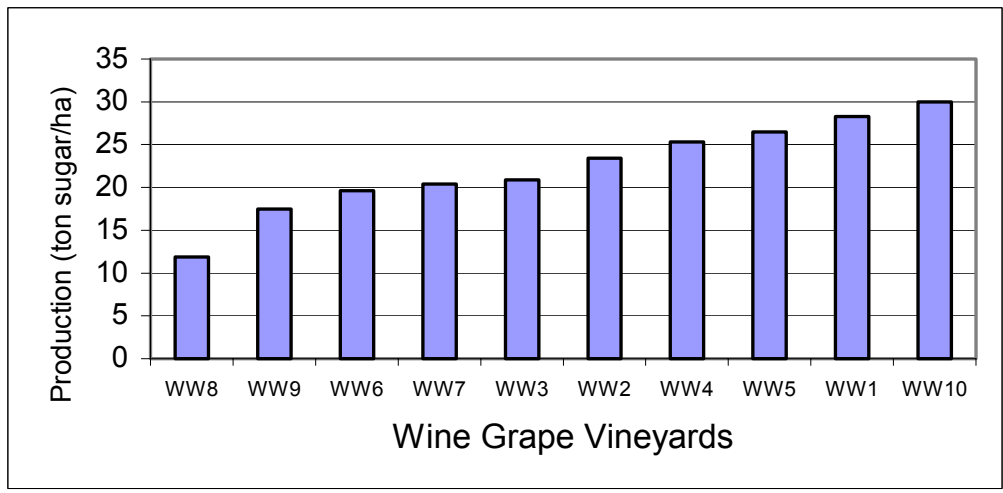

Figure 3: Production of the participating irrigation vineyards 2000/2001 (ton sugar produced/ha).

The WUE ( $\mathrm{kg}$ of sugar produced per $\mathrm{m}^{3}$ of water applied) are shown in Figure 4.

From figures 3 and 4 it becomes clear that the highest production (ton sugar/ha) does not necessarily results in the best WUE $\left(\mathrm{kg}\right.$ sugar $\left./ \mathrm{m}^{3}\right)$. In both 
cases block WW 10 performed the best (30 t/ha and $8,7 \mathrm{~kg} / \mathrm{m}^{3}$ ) while block WW1 had the second best production $(28 \mathrm{t} / \mathrm{ha})$ but only the fourth best WUE $\left(5,1 \mathrm{~kg} / \mathrm{m}^{3}\right)$.

The big differences regarding the tonnage produced and the WUE between different blocks indicates that there is scope for improvement

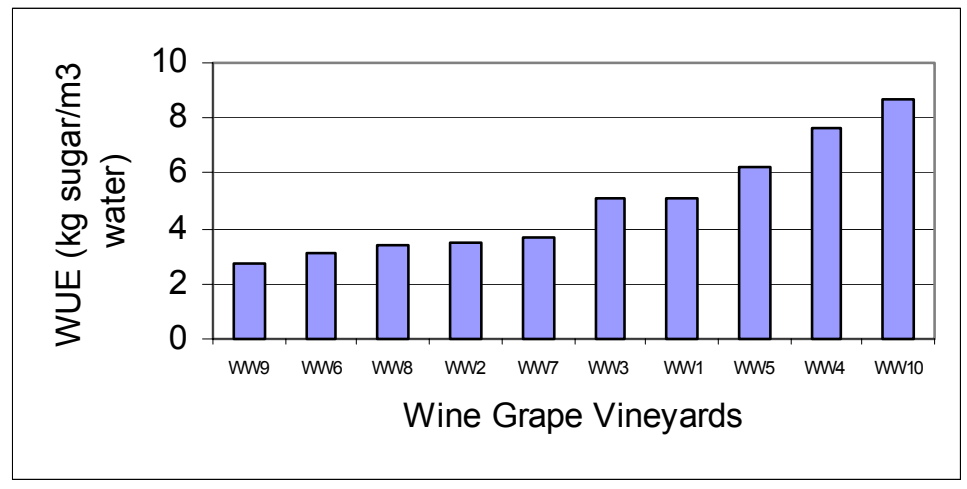

Figure 4: WUE of the participating irrigation vineyards 2000/2001 (kg sugar $\operatorname{produced} / \mathrm{m}^{3}$ water).

Table 1: Average water use and production: Colombar wine grapes (Worcester East).

\begin{tabular}{|l|l|l|l|l|l|}
\hline Season & $\mathbf{9 9 / 0 0}$ & $\mathbf{0 0 / 0 1}$ & $\mathbf{0 1 / 0 2}$ & $\mathbf{0 2 / 0 3}$ & $\mathbf{0 3 / 0 4}$ \\
\hline $\begin{array}{l}\text { Average water use } \\
\left(\mathrm{m}^{3} / \mathrm{ha}\right)\end{array}$ & 4783 & 4957 & 5500 & 4678 & 4608 \\
\hline $\begin{array}{l}\text { Average production } \\
\text { (ton sugar/ha) }\end{array}$ & 22,46 & 22,38 & 29,4 & 28,67 & 27,87 \\
\hline $\begin{array}{l}\text { Average WUE } \\
(\mathrm{kg} \text { sugar/m }\end{array}$ water) & 4,70 & 4,51 & 5,94 & 6,23 & 6,05 \\
\hline
\end{tabular}

The small differences in the data of the 1999/2000 and 2000/2001 seasons can mainly be attributed to various factors. The $\mathrm{ET}_{0}$ was $220 \mathrm{~mm}$ and $240 \mathrm{~mm}$ respectively December 1999 and December 2000. There was a close correlation between the total rainfall figures of the first two irrigation seasons. 2001/02 had very low rainfall, resulting in below field capacity soils after the winter and additional irrigation was required at the onset of the irrigation season.

Although the project led to a decrease of only 3,67\% in water use, the production was significantly increased and the WUE was increased by $28,7 \%$ over the five years of the project.

\subsection{Plums: Cultivar Ruby Nel: Devon Valley, Stellenbosch}

A summary of the results is presented in Table 2 below. 
Table 2: Average water use and production: Ruby Nel plums (Devon Valley).

\begin{tabular}{|l|l|l|l|l|l|}
\hline Season & $\mathbf{9 9 / 0 0}$ & $\mathbf{0 0 / 0 1}$ & $\mathbf{0 1 / 0 2}$ & $\mathbf{0 2 / 0 3}$ & $\mathbf{0 3 / 0 4}$ \\
\hline $\begin{array}{l}\text { Average water use } \\
\left(\mathrm{m}^{3} / \mathrm{ha}\right)\end{array}$ & 7239 & 5585 & 5412 & 7555 & 6408 \\
\hline $\begin{array}{l}\text { Average production } \\
\text { (class 1 and 2) (ton/ha) }\end{array}$ & 12,63 & 21,52 & 20,01 & 27,43 & 19,05 \\
\hline $\begin{array}{l}\text { Average WUE } \\
\left(\mathrm{kg} \text { fruit } / \mathrm{m}^{3} \text { water) }\right.\end{array}$ & 1,99 & 4,12 & 3,87 & 3,73 & 2,87 \\
\hline
\end{tabular}

Rain during the blooming period of the plums in 2003/04 resulted in poor pollination and a huge decrease in the fruit produced. The data indicates that the project made a significant difference to the production and WUE of the various plum orchards with an increase in the WUE of $94,2 \%$ up to $2002 / 03$. Relatively little attention was previously given to the effective use of water. Previously more effort was put into orchard management and other pomological aspects. The value of effective water use came to the forefront with this study and producers bought their own neutron soil probe for use in irrigation scheduling.

\subsection{Table grapes: Cultivar Alphonse Lavaleé: Hex River Valley, De Doorns}

The Hex River Valley is one of the major table grape export areas in our country. Regular water shortages are experienced and one would expect a fairly high level of WUE in the valley. The summarized results are shown in Table 3 below.

Table 3: Average water use and production: Alphonse Lavaleé table grapes (Hex River Valley).

\begin{tabular}{|l|l|l|l|l|l|}
\hline Season & $\mathbf{9 9 / 0 0}$ & $\mathbf{0 0 / 0 1}$ & $\mathbf{0 1 / 0 2}$ & $\mathbf{0 2 / 0 3}$ & $\mathbf{0 3 / 0 4}$ \\
\hline $\begin{array}{l}\text { Average water use } \\
\left(\mathrm{m}^{3} / \mathrm{ha}\right)\end{array}$ & 7182 & 6681 & 7368 & 7144 & 6489 \\
\hline $\begin{array}{l}\text { Average production } \\
\text { (export ton/ha) }\end{array}$ & 20,75 & 22,42 & 29,47 & 26,70 & 23,30 \\
\hline $\begin{array}{l}\text { Average WUE } \\
\left(\mathrm{kg} \text { export fruit } / \mathrm{m}^{3} \text { water) }\right.\end{array}$ & 2,98 & 3,54 & 4,24 & 3,74 & 3,59 \\
\hline
\end{tabular}

During the 2000/2001-season, a couple of thunder storms brought rain to the valley and this reduced the water requirements for irrigation. Damages due to the wet conditions resulted in lower export tonnages than the previous year. Climatic conditions were ideal for table grapes during 2001/02 with resulting high yields and WUE's. An abnormal dry winter in 2003 led to sub-optimal production in 2003/04.

Regular soil moisture readings indicated that although the farmers intended to use their limited water resources efficiently, the availability of water in the root zone of the vines were not sufficient during all the phenological stages of berry 
development. Regular measurement of soil moisture and the accompanied adjustment to their irrigation scheduling brought about the required results.

The project resulted in an average increase of export tonnages of $12,3 \%$ over the 5 years of the project, mainly due to higher quality berries produced and thus a higher percentage of the harvest qualified for export. At the same time, the WUE was increased by $20,5 \%$.

\subsection{Pears: Cultivar: Forel and Packham: Ceres}

Ceres is one of the main apple and pear producing areas in South Africa and climatic conditions play a major role in fruit production. The results are shown in Table 4 below:

Table 4: Average water use and production: Forel and Packham pears (Ceres).

\begin{tabular}{|l|l|l|l|l|l|}
\hline Season & $\mathbf{9 9 / 0 0}$ & $\mathbf{0 0 / 0 1}$ & $\mathbf{0 1} / \mathbf{0 2}$ & $\mathbf{0 2 / 0 3}$ & $\mathbf{0 3 / 0 4}$ \\
\hline $\begin{array}{l}\text { Average water use } \\
\left(\mathrm{m}^{3} / \mathrm{ha}\right)\end{array}$ & 9707 & 9403 & 8676 & 7703 & 7638 \\
\hline $\begin{array}{l}\text { Average production } \\
\text { (export ton/ha) }\end{array}$ & 48,29 & 37,96 & 43,1 & 52,22 & 44,91 \\
\hline $\begin{array}{l}\text { Average WUE } \\
\text { (kg export fruit/m }{ }^{3} \text { water) }\end{array}$ & 5,10 & 4,21 & 4,87 & 6,69 & 5,82 \\
\hline
\end{tabular}

To determine the actual increase in WUE for these orchards proved very difficult due to the fact that the 1999/2000 harvest was the best harvest in many years due to a culmination of climatic and pomological factors and we thus started off with very high production per hectare during 1999/2000.

Over the five years of the project we nevertheless managed to reduce the water consumption by $21,3 \%$ and increased the WUE by $14,1 \%$, with a highest increase in WUE of $31,2 \%$ in 2002/03.

\section{Participants tot the project}

Participants to the project are the Department of Agriculture: Western Cape, the relevant irrigation boards, participating producers, the Western Cape Regional Office of the Department of Water Affairs and Forestry and the Agricultural Research Council (ARC - analyses of soil samples).

\section{Summary}

In order to make provision for the climatologically differences of each year it was decided that the monitoring of water use will be continued for at least three years after the base line information has been gathered. The relative wet summer of the 2001/2002 season, confirmed this decision.

It is not only the climate of a specific irrigation season that impacts on the yield (tonnage and quality) of the crops, but also the climatic factors of the 
previous winter. The most important factors are rainfall, spread of rainfall, temperature, cold units and the climate during flowering.

The project was also extended to include potatoes in the Sandveld area (West Coast region) and wine grapes in the Vredendal region as from the 2002/2003 season.

The project is not completed yet and as such no final recommendations and findings can be made at this stage. It is however clear that in many instances producers strive to use the available water as efficient as possible. The big differences regarding the tonnage produced and the WUE between the different participating irrigation blocks however indicates that there is scope for improvement.

The data that is being collected can also be used in future during the process to evaluate water license applications, which has become compulsory in terms of the National Water Act of 1998. In this evaluation process the effective use of water will play a major role in deciding whether a water use license will be granted.

\section{References}

[1] ASAE Standards, 1998. Field evaluation of micro irrigation systems (EP 458, Dec 97) $45^{\text {th }}$ Edition, Standards Engineering Practices Data.

[2] Burger, J.H. et al. 1996. Irrigation Design Manual. ARC - Institute for Agricultural Engineering, RSA.

[3] Doorenbos, J. \& Pruitt, W.O. 1975. FAO 24. Guidelines for predicting crop water requirements.

[4] FAO 56. 1998. Crop evapotranspiration. Guidelines for computing crop water requirements.

[5] Koegelenberg, F.H. 1997. The effect of the new water policy on the effective use of irrigation water in the Western Cape. Paper presented at the 1997 SAIAE National Symposium. (Afrikaans title: Die invloed van die nuwe waterbeleid op die doeltreffende benutting van besproeiingswater in die Wes-Kaap. Referaat gelewer by die 1997 SAILI Nasionale Simposium).

[6] Koegelenberg, F.H. \& Roux, A.S. 2000. Water Conservation Campaign in Agriculture: Interim Summarized Report.

[7] Murray, Biesenbach \& Badenhorst Consulting Engineers Incorporated. 1997. Towards an Irrigation Policy for South Africa. Summarized results of irrigation workshops held in the Western Cape during May 1997.

[8] National Water Act of South Africa. 1998 (Act 36 of 1998). Department of Water Affairs and Forestry.

[9] Van Zyl, J.L. \& Van Huyssteen. 1998. Irrigation systems. Their role in water requirements and the performance of grapevines. S. Afr. J. Enol. Vitic., Vol. 9, nr. 2. 1998.

[10] Water Research Commission. 1996. Discussion paper: Policy proposal for irrigated agriculture in South Africa. WRC Report KV96/96. 